\title{
Unblocking temperature of secondary magnetic component to outline anomaly thermomagnetic maps of archaeological fireplaces from the southern region of Mexico City, Mexico
}

\author{
Arnaldo Hernández-Cardona ${ }^{1, *}$, Luis Manuel Alva-Valdivia ${ }^{2}$, Guillermo Acosta-Ochoa ${ }^{3}$, \\ Amar Agarwal ${ }^{4}$, Tamara Cruz-y-Cruz ${ }^{3}$, Emily McClung de Tapia ${ }^{3}$
}

\author{
${ }^{1}$ Posgrado en Ciencias de la Tierra, Instituto de Geofísica, Universidad Nacional Autónoma de México, \\ Circuito de la Investigación Científica, C.P. 04510 Mexico City, Mexico. \\ ${ }^{2}$ Laboratorio de Paleomagnetismo, Instituto de Geofísica, Universidad Nacional Autónoma de México, \\ Circuito de la Investigación Científica, C.P. 04510 Mexico City, Mexico. \\ ${ }^{3}$ Instituto de Investigaciones Antropológicas, Universidad Nacional Autónoma de México, \\ Ciudad Universitaria 04510, Mexico City, Mexico. \\ ${ }^{4}$ Institute of Earth and Environmental Sciences, Geology, University of Freiburg, Freiburg, Germany. \\ *ahctetl@ciencias.unam.mx
}

\begin{abstract}
We report a magnetic study of two preceramic hearths located at the southern region of Mexico City. Thermal demagnetization was applied between 200 to $540{ }^{\circ} \mathrm{C}$ to define the remanent magnetization components. The maximum unblocking temperature of the secondary magnetic component reached due to the last heating was identified in most samples. They were used to develop thermomagnetic anomaly source maps. The direction of this component was used to place the blocks to their last cooling spot and configurate a real and primal magnetic anomaly map produced by the thermoremanent magnetization acquired. A protocol to relocate blocks frame is proposed using geomagnetic secular variation curves. The thermomagnetic mapping revealed the position and temperature $\left(220\right.$ to $\left.460{ }^{\circ} \mathrm{C}\right)$ of the last heat sources. The distribution of these sources allowed to model an extensional zone of benefit and probable uses of the hearths.
\end{abstract}

Key words: magnetic anomaly mapping; hearths; Playa Phase; southern Mexico City; Mexico.

\section{RESUMEN}

Reportamos un estudio magnético de dos fogones pre-cerámicos ubicados en la región sur de la Ciudad de México. Se aplicó una desmagnetización térmica entre 200 y $400{ }^{\circ} \mathrm{C}$ para definir las componentes de magnetización remanente. Se identificó la temperatura de desbloqueo máxima de la componente magnética secundaria debida al último calentamiento de la mayoría de las muestras. Esta temperatura se utilizó para elaborar mapas de las fuentes de las anomalías termomagnéticas. La dirección de esta componente se usó para colocar los bloques en la posición de su último calentamiento y así configurar un mapa real de anomalía magnética prehistórica producido por la magnetización termoremanente adquirida. Se propone un protocolo para reubicar los bloques usando curvas de variación secular del campo geomagnético. Los mapas termomagnéticos revelaron la posición y temperatura (200 a $460{ }^{\circ} \mathrm{C}$ ) de las últimas fuentes de calor de cada fogón. La distribución de estas fuentes, permiten modelar la extensión de la zona de beneficio $y$ probable uso de los fogones.

Palabras clave: mapeo de anomalías magnéticas; fogones; Fase Playa; sur Ciudad de México; México.

\section{INTRODUCTION}

It is well known that fire may induce new or effect the pre-existing magnetization in geological materials (Le Borgne, 1960). Some experiments in this sense have been done with applications to paleomagnetism and mineralogy under diverse archaeological context and different burning features (Bellomo, 1993; McClean and Kean, 1993; Morinaga et al., 1999; Linford and Canti, 2001; Maki et al., 2006; Herries, 2009). An important advantage of magnetic techniques is that it can be applied on hearths to identify the temperature of their last use and reconstruct the framework of the constitutive fireplace blocks. It is possible to establish the last position of the blocks after the last burning if a possible blocks assembly is well-known, or if a paleomagnetic direction is known (e.g. secular geomagnetic variation curves or burnt soil) as attested in this work. Additionally, this approach may reveal the purpose of these hearths (Thoms, 2009), such as just for cooking or providing heat to the place, which is a very important archaeological question. Rock magnetic studies have been successfully applied in the past for solving archaeological questions, such as the provenance of archeological artifacts (e.g. Alva-Valdivia et al., 2017) or

Hernández-Cardona, A., Alva-Valdivia, L.M., Acosta-Ochoa, G., Agarwal, A., Cruz-y-Cruz, T., McClung de Tapia, E., 2019, Unblocking temperature of secondary magnetic component to outline anomaly thermomagnetic maps of archaeological fireplaces from the southern region of Mexico City, Mexico: Revista Mexicana de Ciencias Geológicas, v. 36, núm. 3, p. 411-418. 
using the secondary magnetic component to determine the emplacement temperature of volcanic material and the probable date of the eruption (e.g. Alva-Valdivia et al., 2019, among others) or determine the emplacement temperature that could be related to the composite thermal history of the lithic clasts incorporated in a pyroclastic flow (e.g. Alva-Valdivia et al., 2012).

To study an anthropogenic fireplace by using unblocking temperature of the secondary magnetic component, the samples must present stable and distinctive directions. Only thereafter, the secondary remanent magnetization component recorded by the blocks of the hearth can be used for the archaeomagnetic dating (Gose, 2000).

Before sampling for dating fireplaces is necessary to estimate the temperature of the last burning produced ideally by a localized heat source (Morinaga et al., 1999) that produces the secondary magnetic directional component.

We used thermal demagnetization on particular pilot specimens to determine the parts of temperature with the highest probability to find the reliable secondary component. Magnetic experiments, e.g. susceptibility vs. high-temperature (k-T) curves and magnetic hysteresis analysis were performed to better understand the magnetic signals.

Two hearths of preceramic settlement in the archaeological site of San Gregorio Atlapulco, Xochimilco, southern Mexico City (Figure 1) were studied with the unblocking temperature of the secondary magnetic component method. This horizon corresponds to a human occupation of the Preceramic Playa Phase, ca. 6000 to 4500 BCE. This archaeological site was first reported in the regional study by Jeffrey Parsons (Parsons et al., 1982) who made the first map of the site of the mounds on the platform. Subsequently, in 1990 the area was subjected to archaeological rescue by López (1995) due to the construction of an irrigation district that destroyed almost $90 \%$ of the archaeological mounds. In his excavations, López (1995) was able to identify six layers, the last two corresponding to the preceramic occupation, and tentatively placed the occupation between the 2500-2000 BCE (López, 1995). Unfortunately, the results presented in the final report of the site does not include radiocarbon dating or detailed botanical studies. Thus in 2013 new excavations were carried out on the site through the Universidad Nacional Autónoma de México (UNAM) project "The development of agrarian societies in the Basin of Mexico", to obtain reliable data of the occupational chronology and the subsistence of these first lacustrine villages (McClung and Acosta, 2015; Acosta, 2017).

The site has two excavation units: Unit A $\left(49 \mathrm{~m}^{2}\right)$, located at the highest part of the platform, corresponding to the area partially excavated in 1994, when the preceramic occupation of the site was discovered (López, 1995); Unit B $\left(280 \mathrm{~m}^{2}\right)$ is located at the eastern end of the platform where the leveling of the platform had exposed a couple of fireplaces with remains of pestles and mortars of the Playa II phase (5500-4500 cal B.C.E). In unit B, just the surface layer was excavated and found lithic artifacts of obsidian, basalt and chalcedony, as well as residues of birds, fish, and mammalian bones, and the two associated large hearths.

These hearths are well identified as combustion features used in a semi-permanent or seasonal occupation (Mentzer, 2014). However, their utility, either exclusively for cooking or also for warming up the habitational area is still disputed. A systematic approach using different analyses can demonstrate the activities and specific surrounding of the hearth (e.g., Barbetti, 1986; Stevenson, 1991; Bellomo, 1993, 1994).

In this paper, the magnetic mineralogy determined by rock magnetic properties, the relationship between magnetic susceptibility and the direction of the secondary magnetization are related to the isotherms that aid in the configuration of the various sources of temperature distribution during the last burning in the fireplaces.

\section{METHODOLOGY}

The samples were taken from the volcanic blocks that formed the hearths (Figure 1b). The blocks are ca. $20 \mathrm{~cm}$ long, coming probably from the Chichinautzin volcanic field that surrounds the Mexico Basin and have basaltic-andesite composition in general. They were strongly embedded in the cover of soil under the hearth. Sampling distribution of the blocks in hearth 1 was random and selective, unlike sampling on hearth 2 that all blocks were drilled. Cylindrical cores were obtained with a gasoline powered motor using a diamond drill bit. Cores are 1 inch in diameter and mostly $3-5 \mathrm{~cm}$ in length depending on the block size. The cores were cut into $2.2 \mathrm{~cm}$ long specimens.

The magnetic mineralogy was primarily implied by k-T curves. Variations in susceptibility at low fields, from room temperature (RT) to $680^{\circ} \mathrm{C}$ (Figure 2) was measured for 12 blocks from both hearths. These measurements were performed with a Bartington susceptibility system (MS2) at the Instituto de Geofísica, UNAM, Mexico City. Further mineralogical investigation was done by studying polished sections of some specimens under microscope reflected light. The magnetic domain size distribution was investigated by hysteresis cycles with a maximum applied field up to $1.0 \mathrm{~T}$ at ambient temperature
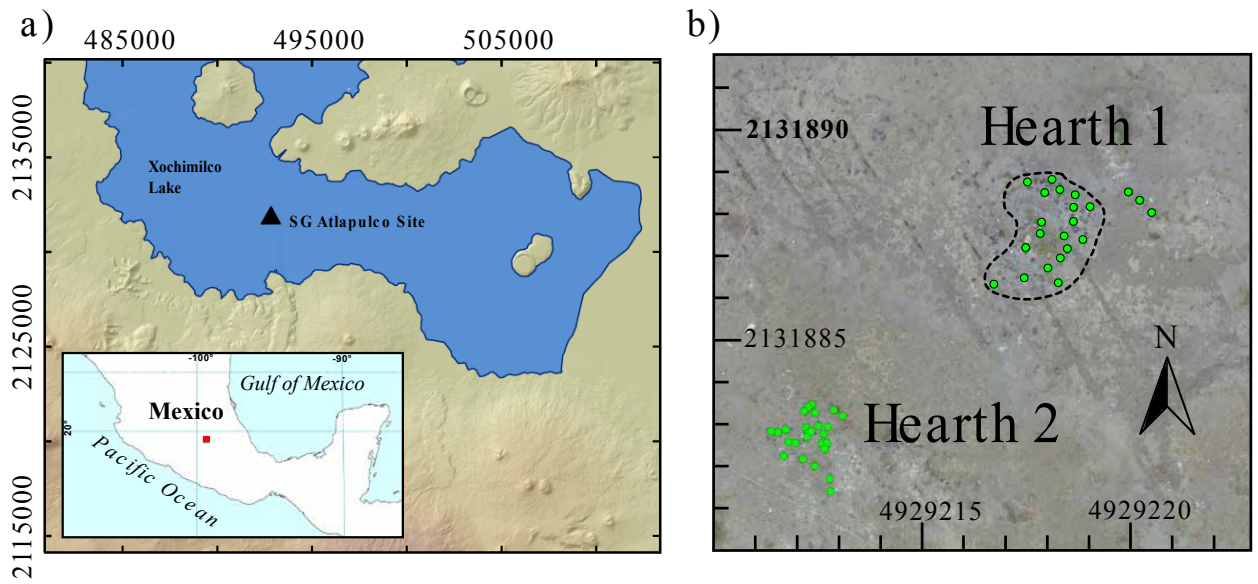

Figure 1. a) Location of the San Gregorio Atlapulco site, Xochimilco (black triangle), in southern Basin of Mexico. Blue is a representation of the paleolake where Mexico City is now established. b) Geoposition of both Hearths. Hearth 1 limit is marked by a black striped line. The blocks were strongly embedded in the soil. This structure is $4 \mathrm{~m}$ along its major axis. Both hearths are in aerial view, inset (Datum UTM 14Q, WGS84). 

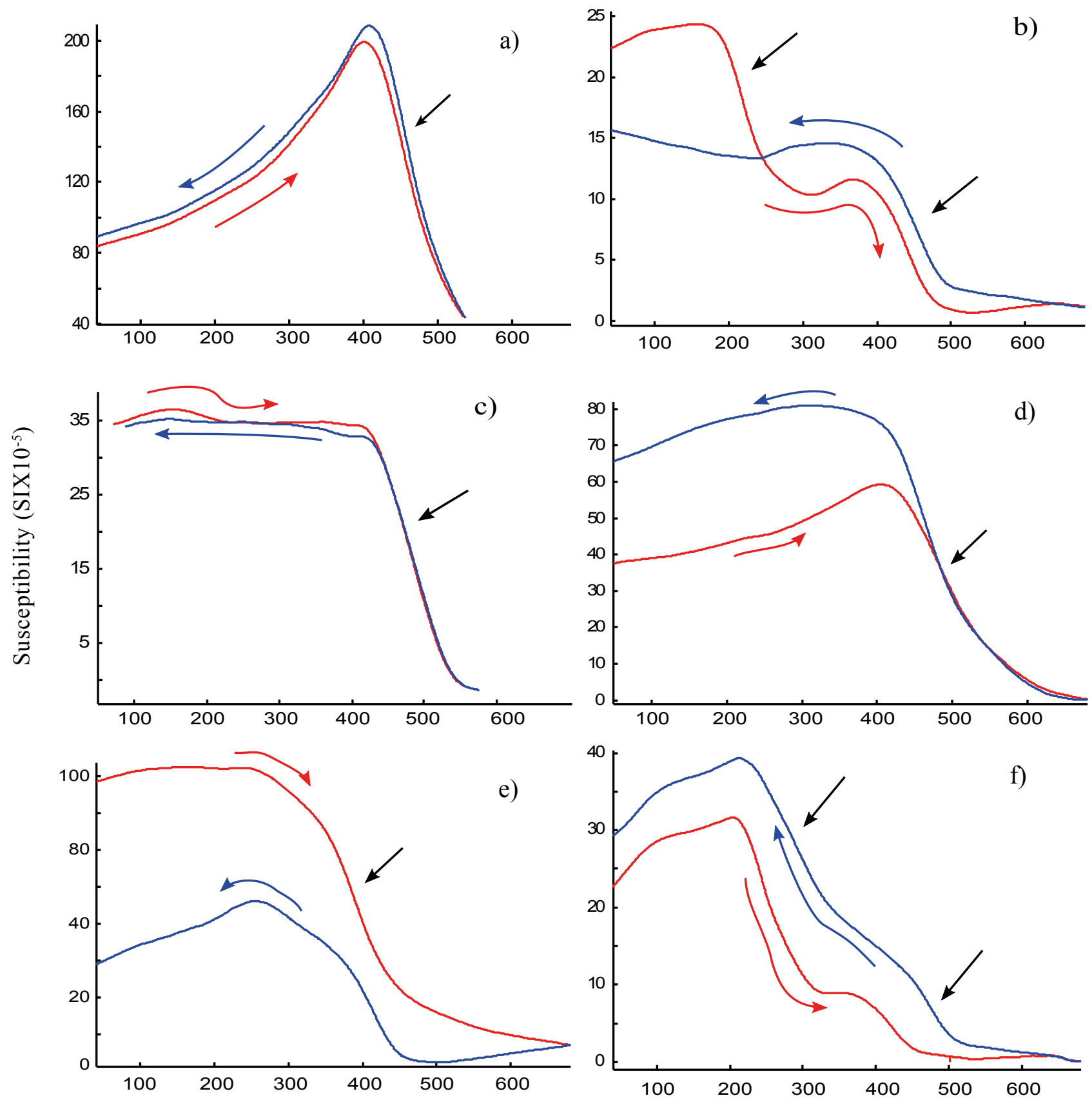

Temperature $\left({ }^{\circ} \mathrm{C}\right)$

Magnetic susceptibility (SI units) vs. temperature. Curves of three representative samples from each hearth, a-c belong to Hearth 1 and d-f belong to Hearth 2 . The Curie temperature is calculated by the second derivative approximation marked by black arrows.

using an Advanced Variable Field Translational Balance at the Centro de Investigación Científica y de Educación Superior de Ensenada (CICESE), Baja California Norte, México. The k-T and hysteresis curves were used to infer the magnetic mineralogy.

Various magnetic components were determined by identifying the complete spectrum of blocking temperatures. Changes are identified through thermal demagnetization by step-wise progressive heating of the samples, from RT to the Curie temperature (Tc) and measuring the residual remanence after each step. The magnetization components represent a specific episode of physical and chemical conditions of the heating. In volcanic rocks, the characteristic remanent magnetic component (ChRM) represents the geomagnetic field at the time of their cooling from the magma. Secondary components are associated with the heating episodes during subsequent use of the hearths.

We use an MMTD furnace for the heating, employing incremental steps of $50^{\circ} \mathrm{C}$ between 100 and $200^{\circ} \mathrm{C}$, of $20^{\circ} \mathrm{C}$ between 200 and 300 ${ }^{\circ} \mathrm{C}$, and of $15{ }^{\circ} \mathrm{C}$ between 300 and $540{ }^{\circ} \mathrm{C}$. We measure the residual magnetization after each heating using a JR6 spinner magnetometer. 


\section{RESULTS}

\section{Magnetic properties}

The $\mathrm{k}$-T curves reveal several Tc, and thus, multiple ferrimagnetic carriers. Most of the curves are irreversible, may be due to a metastable ferrimagnetic component that is removed at higher temperatures. Most of the curves show a single Tc between 400 and $470{ }^{\circ} \mathrm{C}$ (Figure $2 \mathrm{a}, 2 \mathrm{c}$, $2 \mathrm{~d}, 2 \mathrm{e})$. Some other curves reveal a couple of ferrimagnetic carriers with high Tc from 419 to $439^{\circ} \mathrm{C}$ and, low Tc between 216 and $242{ }^{\circ} \mathrm{C}$ (Figure $2 \mathrm{~b}, 2 \mathrm{f}$ ). The Tc belong to titanomagnetite with medium $\mathrm{Ti}$ content $\left(0.1<X_{U s p}<0.3\right)$. Tc may indicate titanomaghemite which is a metastable phase and commonly decomposes at high temperatures. The low temperature Tc may be a representative of some other metastable phase with low Curie temperature.

All samples glimpse a PSD behavior, revealing a mixture of SD and $\mathrm{MD}$, with major $\mathrm{SD}$ proportion in the typical hysteresis curves of both hearths (Figure 3). The most common hysteresis curves have mean $\mathrm{Hc}=22.55 \mathrm{mT}$. However, we found less common Hc minimum and maximum values of 8.19 to $47.88 \mathrm{mT}$, respectively.

\section{Magnetic component analysis}

Reheating of hearth blocks can be detected by secondary magnetization components in the Zijderveld plots, equal area direction stereoplots and intensity of magnetization diagrams. There are many distinct processes that create a secondary magnetization (Dunlop, 1979). In our case, stable magnetic mineral phases attain one or more secondary magnetization component, each with a specific blocking temperature for each component. Same direction of the geomagnetic field at each reheating event (Figure $4 \mathrm{~b}$ and $5 \mathrm{~b}$ ), with step-like in the intensity of magnetization (Figure $4 \mathrm{a}$ and $5 \mathrm{a}$ ) shows this unique blocking temperature for each component. In most of the samples, the dispersion of blocking temperature spectrum is well confined and there is no overlapping between components.

We observed several secondary components, as follows: (1) All samples have Component 3 with blocking temperature between 390 and $480^{\circ} \mathrm{C}$; (2) Many of the samples shows Component 1 with blocking temperature between room temperature and 200 to $240{ }^{\circ} \mathrm{C}$; and (3) Few cases show Component 2 with blocking temperature between 315 and $\mathrm{ca} .420^{\circ} \mathrm{C}$.

\section{Magnetic anomaly configuration (thermomagnetic mapping)}

From the second and third magnetic component associated with the lasts heating the two different temperatures, we interpolate the main heat sources by minimal curvature isotherms. For Hearth 1, two heat sources found with second component temperature about the center of the hearth (Figure $4 \mathrm{~d}, 4 \mathrm{~g}$ ) and three different sources with a N-S alignment as same as the second components heat sources (Figure 4e, 4h). Also, Hearth 2 shows two second component heat sources with alignment E-W (Figure 5d, 5g). The third component sources are far equal distance from each other with a N-S alignment between the two smaller sources. (Figure 5e, 5h).

Assuming an occupation between 6000 and 4500 BCE (calibrated dates, McClung and Acosta 2015), we choose a range of the magnetic direction (declination and inclination) in the SHA.DIF.14K curve (Pavón-Carrasco et al., 2014). The direction of all moved blocks was compared with a mean declination $\theta_{m}=359.5^{\circ}$ and mean inclination $\lambda_{m}=38.2^{\circ}$ of the choosed range in the paleosecular variation data model, in order to be used for the reorientation analysis.

To re-adjust the thermomagnetic mapping for accommodating the movement of the blocks, we used two assumptions: a) blocks were moved after last heating, b) blocks were displaced but were not anthropogenically heating thus preserving the original magnetization.
These possibilities produce untrue heat sources that can be removed with a reorientation analysis of the blocks (Figure 4 and $5 \mathrm{f}-5 \mathrm{~h}$ ).

The movement of blocks after-during the heating-cooling process is the most probable assumption for the final position of the blocks in both hearths. We assume two hypotheses for the re-orientating calculation. First, the rotation is given over the surface of a sphere $10 \mathrm{~cm}$ in diameter $(d)$ (Figure 6). Second, no movement is considered if the block exceeds a rotation of $(d \pi) / 4$. The original declination angle $\theta=\Sigma \theta_{i}$ where $\theta_{i}$ is the declination angle of each component with $\mathrm{i}=1,2,3$, and the same for the original inclination angle $\lambda_{0}=\Sigma \lambda_{i}$. The original position in $x-y$ coordinates remains for a simple Polar-to-Cartesian transformation for the horizontal plane.

\section{DISCUSSION}

The outer limit of the hearth is marked by the $30^{\circ} \mathrm{C}$ isogon. Neither of the two hearths has a geometrical shape (Figure 4 and 5). The shape was, thus, not important to the builders. The hearths may have been a non-permanent structure, changing in shape and block arrangement as per the necessities of the users. This would explain the possible movement of blocks. Moreover, the highest temperatures are recorded in the central part for the temperature of Component 2 (Figure 4 and $5 \mathrm{~d}, 5 \mathrm{~g})$ and near the extremities for temperatures of Component 1 and 3 (Figure 4 and 5c, 5e, 5f, 5h), indicating the partial use of the hearths. The maximum temperature inferred on the thermomagnetic mapping is $480^{\circ} \mathrm{C}$, which is sufficient for cooking food and heating the habitat.

The secondary components indicate a distinctive anthropological usage of the hearth structures. The heating up to ca. $220^{\circ} \mathrm{C}$ could have been used to warm the surroundings places. The temperature between 390 to $480{ }^{\circ} \mathrm{C}$ could be related to longer and larger settles including both activities of warming and cooking. Three temporary uses could be distinguished from these components. Component 1 erase information of Component 2 and 3, and so on for intermediate and high. Also, the high temperature component is the first one registered and the low temperature is the last one revealing these temporary uses.

After the orientation correction, heat sources show a N-S oriented triangular configuration (Figure $4 \mathrm{~h}$ and $5 \mathrm{~h}$ ). Remarkably such configuration is not seen using the non-corrected samples (Figure 4 and $5 c-5 e)$.

The size and maximum temperature of the heat source are compared in Figure 7 with the spatial distribution of the artifacts found

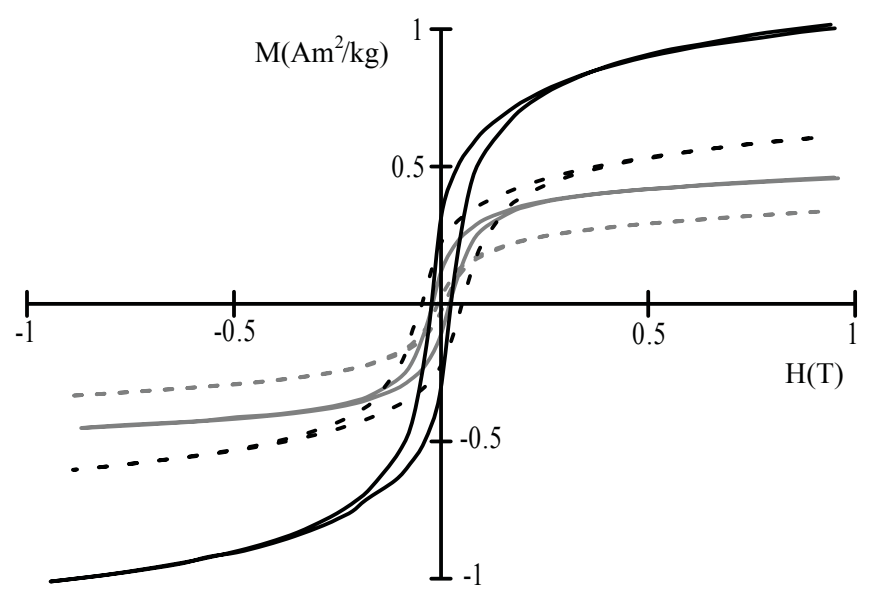

Figure 3. Examples of typical hysteresis curves for Hearth 1 in grey, and Hearth 2 in black. Most common curves are a continuous line. 
c)

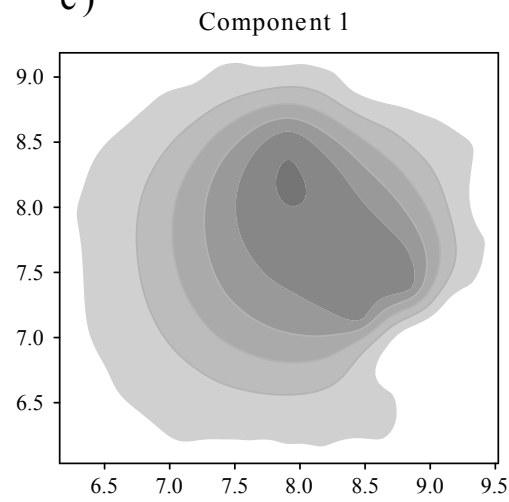

d)

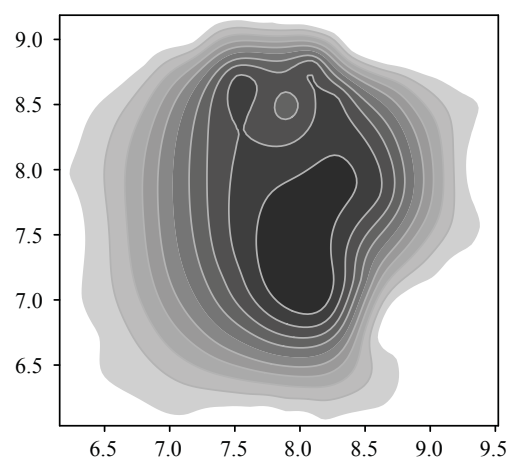

e) Component 3

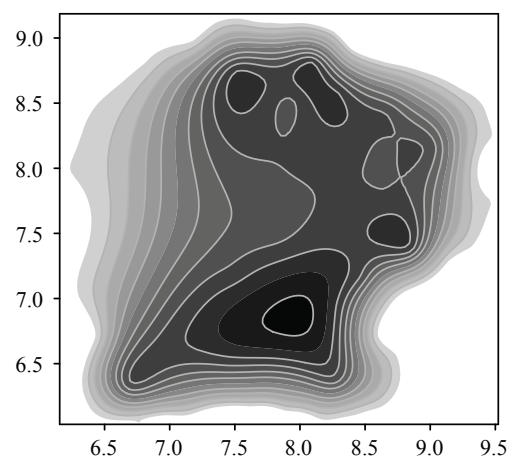

a)

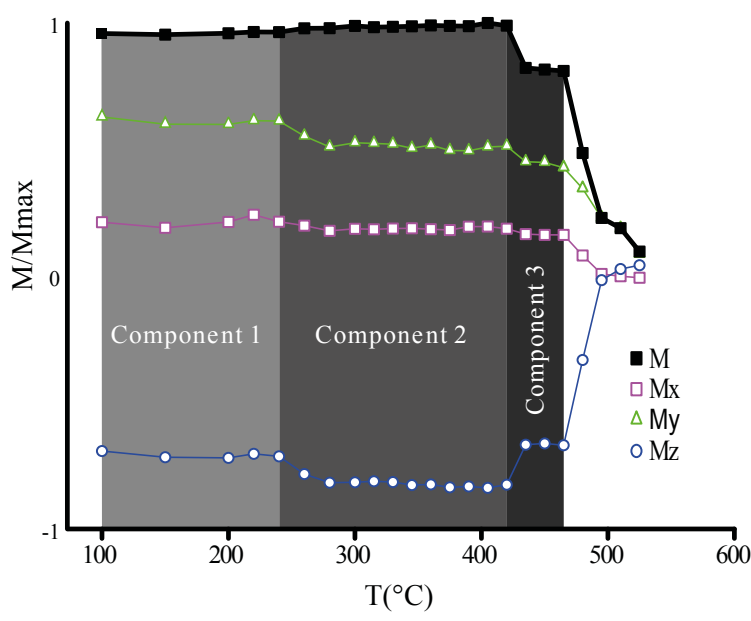

b)

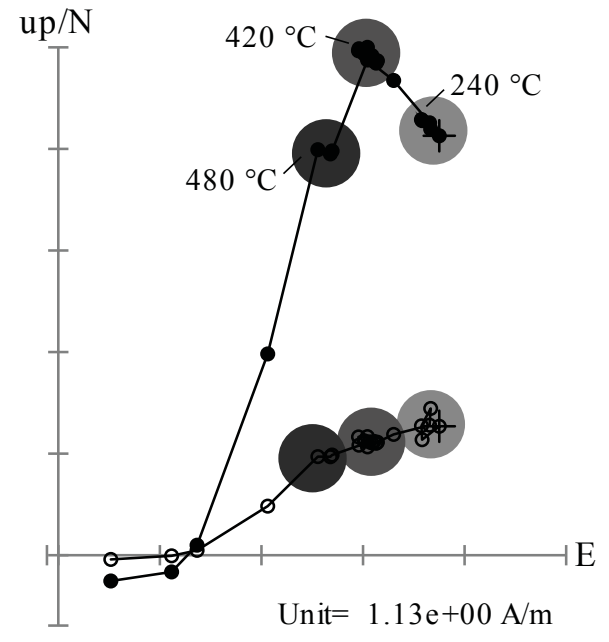

$\begin{array}{lllllllllllll}580 & 530 & 480 & 430 & 380 & 330 & 280 & 230 & 180 & 130 & 80 & 30\end{array}$ $\mathrm{T}\left({ }^{\circ} \mathrm{C}\right)$ f)

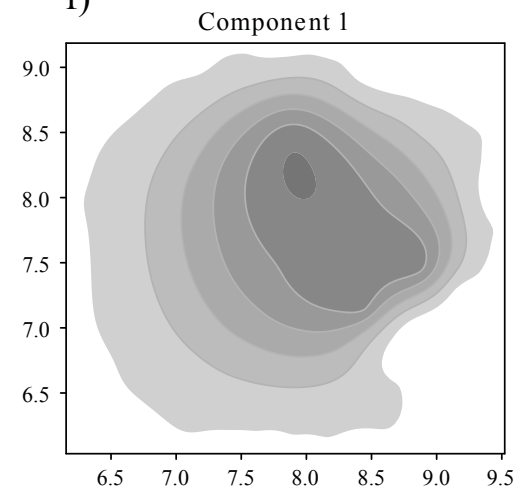

g)

Component 2

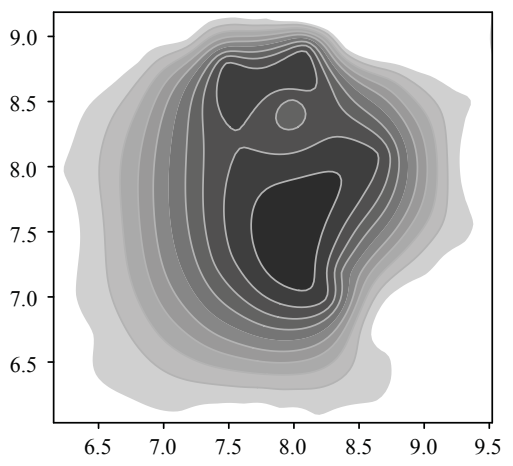

h)

Component 3

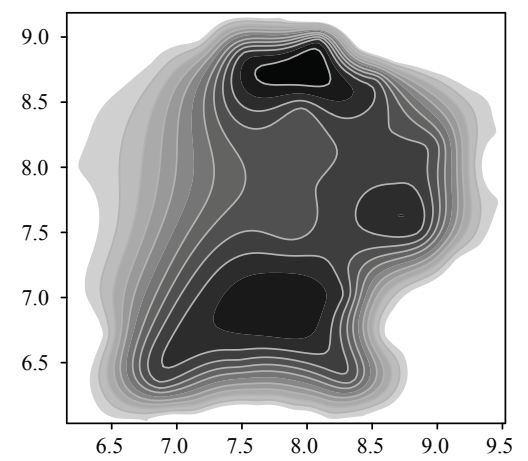

Figure 4. Demagnetization spectra (a) sample from Hearth 1 with three temperature components: Component 1 , up to ca. $240{ }^{\circ} \mathrm{C}$, Component 2 , between 240 and $420^{\circ} \mathrm{C}$, and Component 3 , from 420 to $465^{\circ} \mathrm{C}$. The three-axis of the intensity of magnetization ( $\left.\mathrm{Mx}, \mathrm{My}, \mathrm{Mz}\right)$ show a more precise identification of temperature components. b) The corresponding Zijderveld diagram displays the three directional components. Three components (c to e) of the thermomagnetic map using the original sampling position, and the same components ( $\mathrm{f}$ to $\mathrm{h}$ ) using the reoriented sample position (see text). Scale in thermomagnetic maps is in meters.

in the vicinity (McClung and Acosta, 2015). The greater the source the bigger density of artifacts, suggesting the importance of the extension of heat sources compared with heat intensity. The spatial distribution coincides with the ethnographic record, that places the Hearth 2 as the focus of domestic and ritual activities among hunter-gatherer groups, such that other archaeological materials are often distributed around them (Binford, 1980; Bellomo, 1993, 1994).

Small reorienting movements of blocks (less than $15 \mathrm{~cm}$ ) around the sampling position is enough to set an arrangement of blocks nearly to the original position. This is possible using blocks size near a sphere of $10 \mathrm{~cm}$ in diameter and $20 \mathrm{~cm}$ of separation between blocks. This reorienting process gets complicated if the ground has a slope or other mechanical alterations are visible in the structure.

\section{CONCLUSIONS}

This is a novel procedure to create a thermomagnetic map of archeological hearths. We got the approximated temperature of prece- 
c)

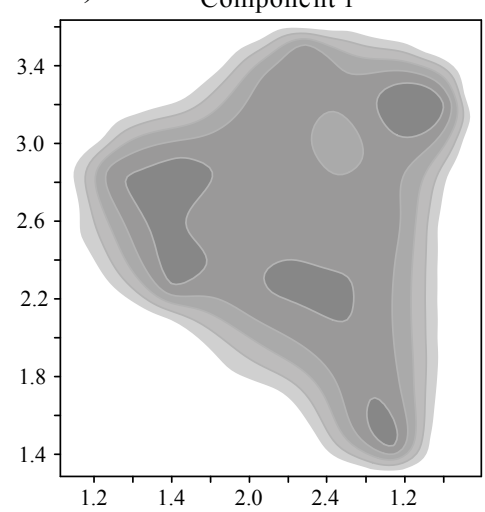

d)

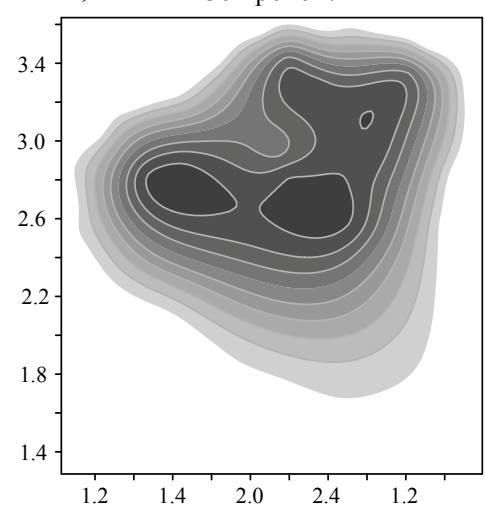

e)

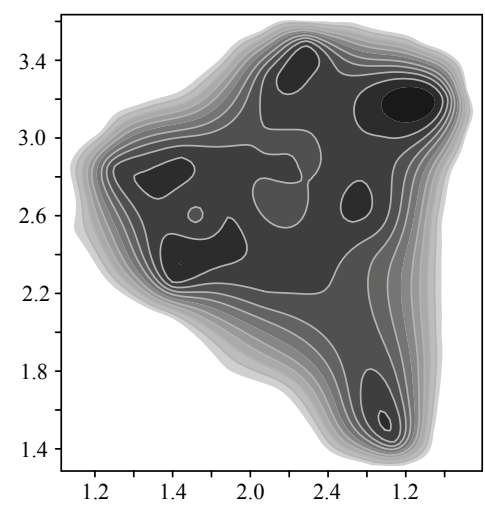

a)

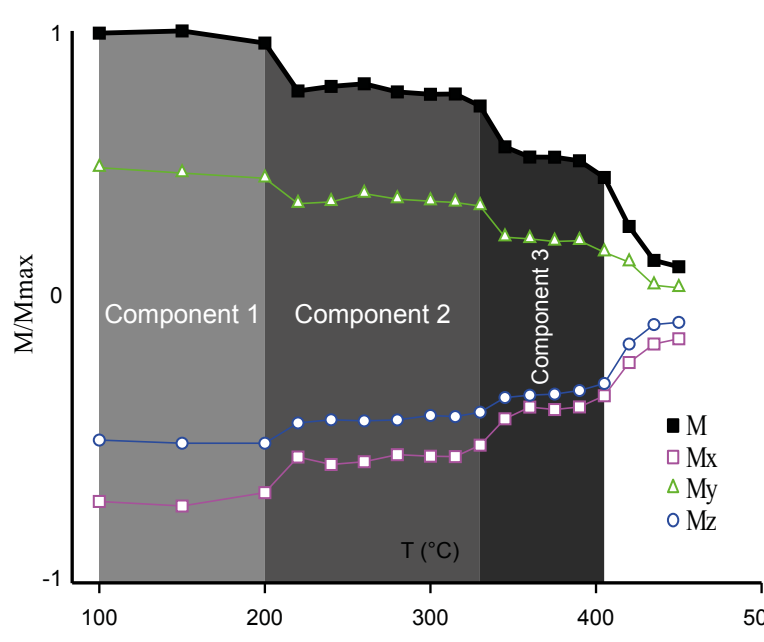

b)
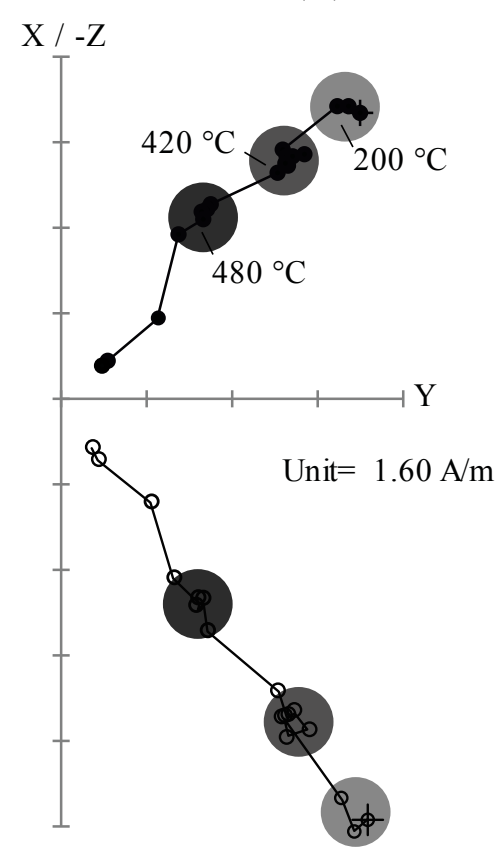

$\begin{array}{llllllllllll}580 & 530 & 480 & 430 & 380 & 330 & 280 & 230 & 180 & 130 & 80 & 30\end{array}$

$\mathrm{T}\left({ }^{\circ} \mathrm{C}\right)$ f)

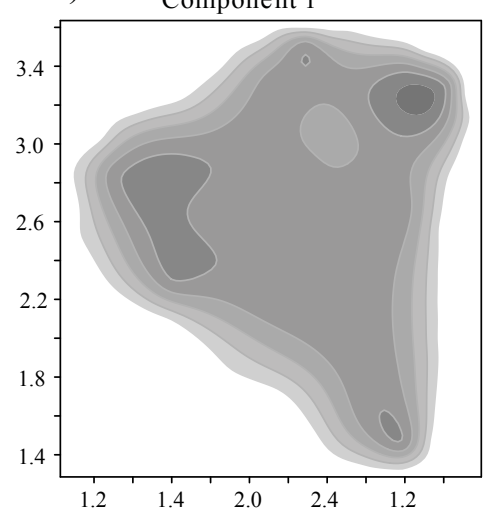

g)

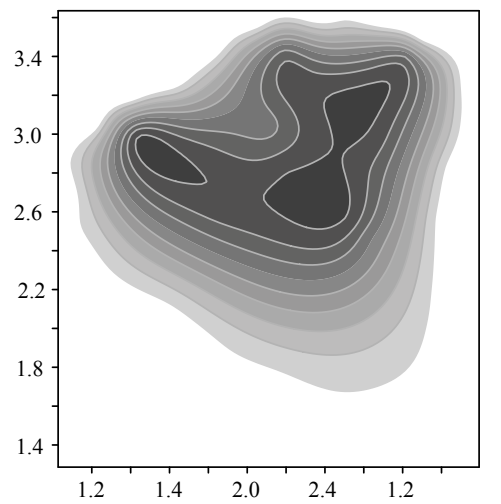

h)

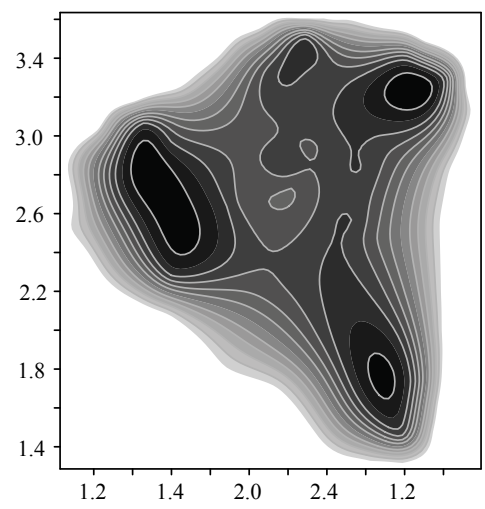

Figure 5. Demagnetization spectra (a) sample from Hearth 2 with three temperature components: Component 1 up to ca. $200{ }^{\circ} \mathrm{C}$, Component 2 and Component 3 from 420 to $465^{\circ} \mathrm{C}$. b) Corresponding Zijderveld diagram sample displaying three component direction. Three components (c to e) of the thermomagnetic map using the original sampling position and the same components ( $\mathrm{f}$ to $\mathrm{h}$ ) using the reoriented sample position (see text). Scale in thermomagnetic maps is in meters.

ramic fireplaces using the secondary magnetic component registered by the blocks. A spatial distribution of heat sources was acquired by using the configuration of the magnetic anomaly (thermomagnetic mapping). The distribution and extension of the heat sources provide further knowledge on the use of the settlement. Magnetic mineralogy varies significantly in each block owing to distinct volcanic provenances of the blocks.

Reorganization of blocks is only possible with the paleomagnetic analysis that includes magnetic mineralogy measurements to investigate the stability behavior of the directional analysis of magnetic com- ponents. A more complex hypothesis for the reorienting calculation will improve the archaeological discussion of this sort of structures.

\section{ACKNOWLEDGEMENTS}

This study was possible thanks to the financial support granted by Consejo Nacional de Ciencia y Tecnología (CONACyT I0017, Mexico, ANR-CONACyT 273564, France-Mexico) and the PAPIIT-UNAM research projects IG400217 and IN113117. 


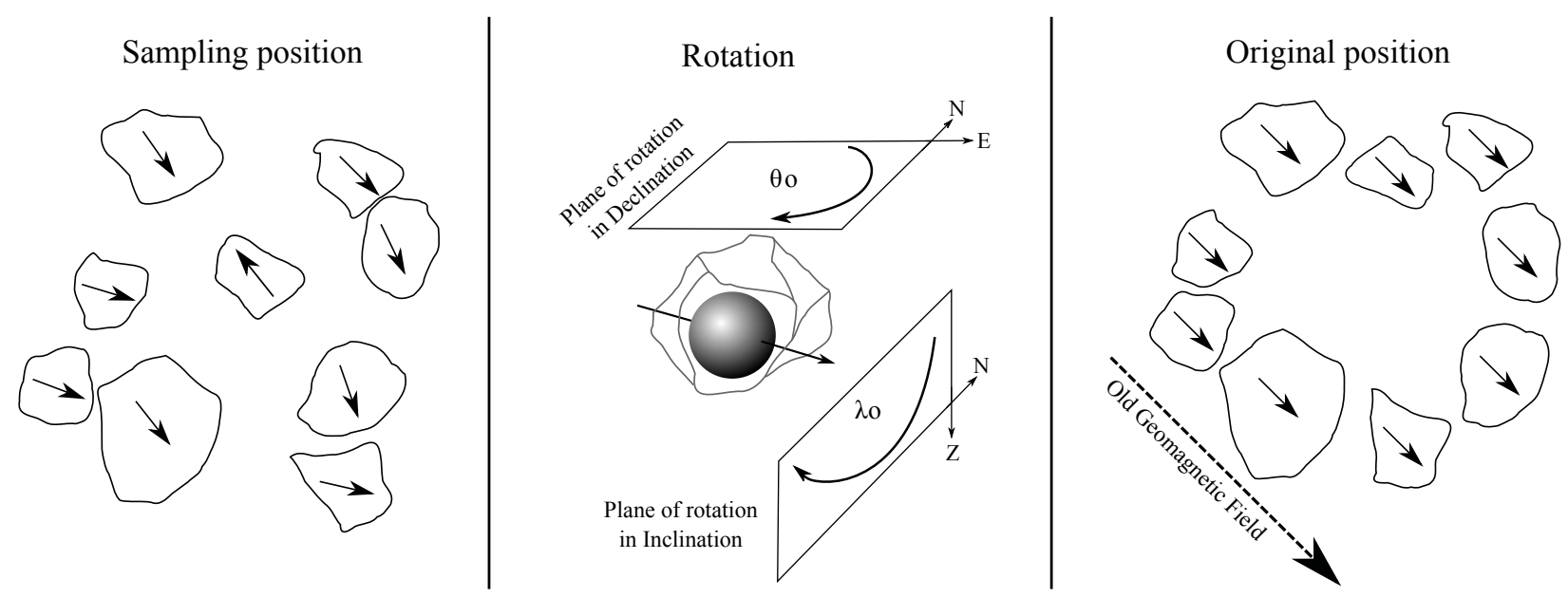

Figure 6. Procedure to re-orient the block to the original position. Two hypothesis were considered for this calculation (see text). The arrows represent the vector of magnetic remanence.

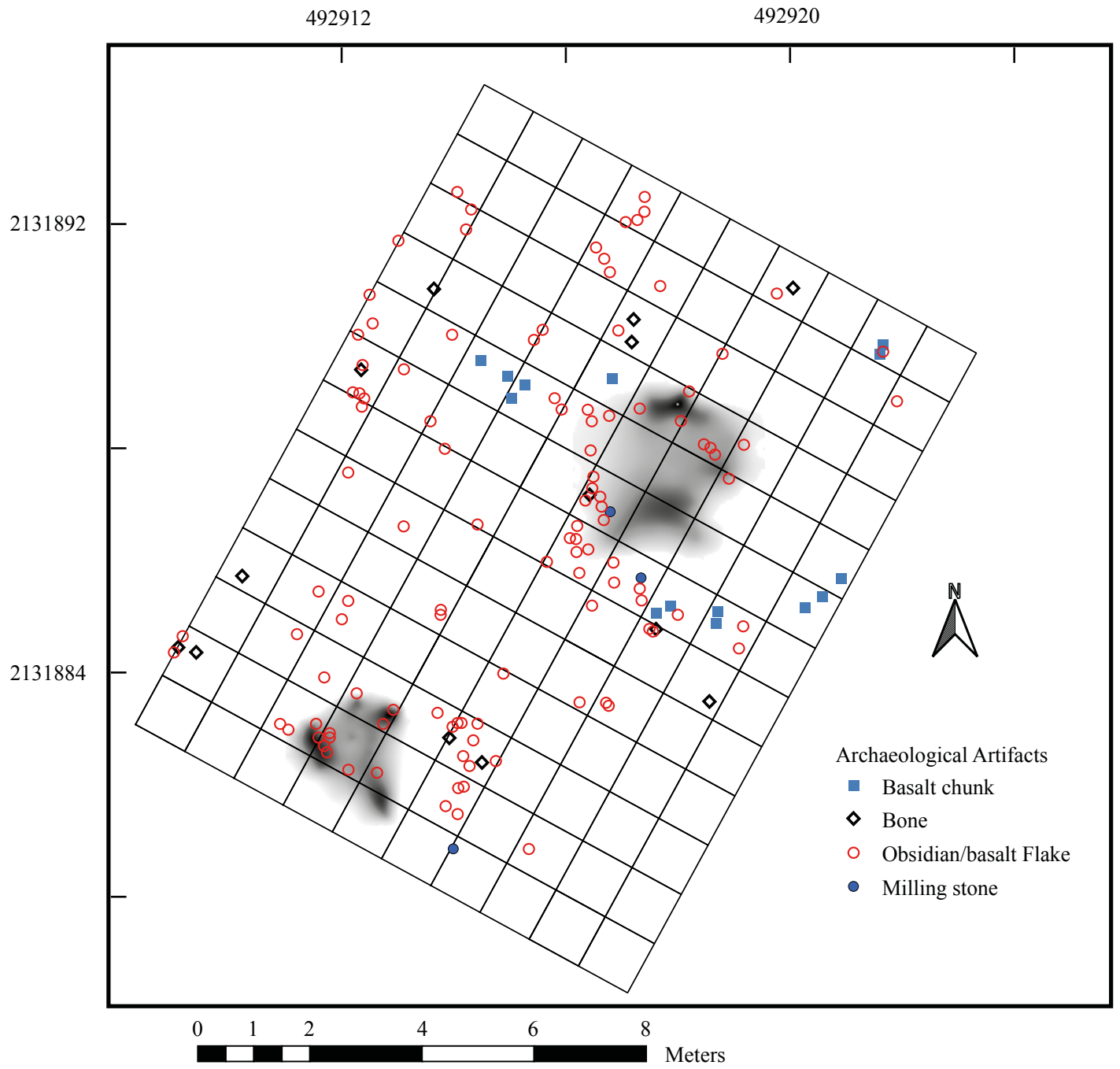

Figure 7. Spatial distribution of artifacts and hearths of Unit B, San Gregorio Atlapulco. 


\section{REFERENCES}

Acosta G., 2017, Early agricultural modes of production in Mesoamerica: New insights from southern and central Mexico, in Rosenswig, R.M., Cunningham, J.J. (eds.) Modes of Production and Archaeology: University Press of Florida, 73-96.

Alva-Valdivia, L.M., Torres-Hernández, J.R., González-Rangel, J.A., CaballeroMiranda, C.I., Rosas-Elguera, J.G., Villalobos-Romero, N., 2012, Paleomagnetismo en la determinación de temperatura de emplazamiento de la Ignimbrita Panalillo, Juachín, San Luis Potosí, México: Revista Mexicana de Ciencias Geológicas 29, 3, 619-638.

Alva-Valdivia, L.M., Cyphers, A., Rivas-Sánchez, M.L., Agarwal, A., ZuritaNoguera, J., Urrutia-Fucugauchi, J., 2017, Mineralogical and magnetic characterization of Olmec ilmenite multi-perforated artefacts and inferences on source provenance: European Journal of Mineralogy, 29(5), 851-860, doi: 10.1127/ejm/2017/0029-2654.

Alva-Valdivia, L.M., Rodríguez-Trejo, A., Vidal-Solano, J.R., Paz-Moreno, F.,Agarwal, A., 2019, Emplacement temperature resolution and age determination of Cerro Colorado tuff ring by TRM analysis, El Pinacate Volcanic Field, Sonora, Mexico: Journal of Volcanology and Geothermal Research, 369, 145-154, https://doi.org/10.1016/ j.jvolgeores.2018.11.012

Barbetti, M., 1986, Traces of fire in the archaeological record, before one million years ago?: Journal of Human Evolution, 15(8), 771-781.

Bellomo, R.V., 1993, A Methodological Approach for Identifying Archaeological Evidence of Fire Resulting from Human Activities: Journal of Archaeological Science, 20(5), 525-553.

Bellomo, R.V., 1994, Methods of determining early hominid behavioral activities associated with the controlled use of fire at FxJj 20 Main, Koobi Fora, Kenva: Journal of Human Evolution, 27(1-3), 173-195.

Binford, L.R., 1980, Willow smoke and dogs' tails: hunter-gatherer settlement systems and archaeological site formation: American Antiquity, 45(1), 4-20

Dunlop, D.J., 1979, On the use of Zijderveld vector diagrams in multicomponent paleomagnetic studies: Physics of the Earth and Planetary Interiors, 20(1), $12-24$.

Gose, W.A., 2000, Palaeomagnetic studies of burned rocks: Journal of Archaeological Science, 27(5), 409-421.

Herries, A.I.R., 2009, New approaches for integrating palaeomagnetic and mineral magnetic methods to answer archaeological and geological questions on Stone Age site, in Fairbrain, A., O'Conner, S., Marwick, B. (eds.), Terra Australis 28 - New Directions in Archaeological Science: The Australian National University Press, Canberra, Australia, Chapter $16,235-253$.

Le Borgne, E., 1960, Influence du feu sur les propriétés magnétiques du sol et sur celles du schiste et du granite: Annales de Géophysique, 16, 159.
Linford, N.T., Canti, M.G., 2001, Geophysical evidence for fires in antiquity: preliminary results from an experimental study. Paper given at the EGS XXIV General Assembly in The Hague, April 1999, Archaeological Prospection, 8(4), 211-225.

Lopez A.R., 1995, Excavaciones arqueológicas en San Gregorio Atlapulco, Xochimilco. Reporte presentado a la Subdirección de Salvamento Arqeuológico: Ciudad de México, Instituto Nacional de Antropología e Historia.

Maki, D., Homburg, J.A., Brosowske, S.D., 2006, Thermally activated mineralogical transformations in archaeological hearths: Inversion from maghemite $\gamma \mathrm{Fe} 2 \mathrm{O} 4$ phase to haematite $\alpha \mathrm{Fe} 2 \mathrm{O} 4$ form: Archaeological Prospection, 13(3), 207-227.

McClung, E., Acosta, G., 2015, Una ocupación del periodo de agricultura temprana en Xochimilco (ca. 4200-4000 a.n.e.): Anales de Antropología, 49(2), 299-315.

McClean, R.G., Kean, W.F., 1993, Contributions of wood ash magnetism to archaeomagnetic properties of fire pits and hearths: Earth and Planetary Science Letters, 119(3), 387-394.

Mentzer, S.M., 2014, Microarchaeological approaches to the identification and interpretation of combustion features in prehistoric archaeological sites: Journal of Archaeological Method and Theory, 21(3), 616-668.

Morinaga, H., Inokuchi, H., Yamashita, H., Ono, A., Inada, T., 1999, Magnetic detection of heated soils at paleolithic sites in Japan: Geoarchaeology, 14(5), 377-399.

Parsons, J., Brumfield, E., Parsons M., Wilson, D., 1982, Prehispanic Settlement Patterns in the Southern Valley of México, The Chalco- Xochimilco Región. Memoirs of the Museum of Antropology 14. University of Michigan, Ann Arbor. (1955) Nota preliminar sobre los restos humanos subfósiles de Santa María Aztahuacán, D.F: Anales del INAH, 7, 65-74.

Pavón-Carrasco, F.J., Osete, M.L., Torta, J.M., De Santis, A., 2014, A geomagnetic field model for the Holocene based on archaeomagnetic and lava flow data: Earth and Planetary Science Letters, 388, 98-109.

Stevenson, M.G., 1991, Beyond the formation of hearth-associated artifact assemblages, in The interpretation of archaeological spatial patterning: Springer U.S., 269-299.

Thoms, A.V., 2009, Rocks of ages: propagation of hot-rock cookery in western North America: Journal of Archaeological Science, 36(3), 573-591.

Manuscript received: june 8, 2019

Corrected manuscript received: august 27, 2019

Manuscript accepted: august 27, 2019 